\title{
Selection of Planned Supply Initiatives: The Role of Senior Management Expertise
}

\author{
P. Fraser Johnson ${ }^{* a}$ \\ The University of Western Ontario \\ Robert D. Klassen $^{\text {a }}$ \\ The University of Western Ontario \\ Michiel R. Leenders ${ }^{a}$ \\ The University of Western Ontario \\ Amrou Awaysheh ${ }^{\text {a }}$ \\ The University of Western Ontario \\ ${ }^{a}$ Richard Ivey School of Business, The University of Western Ontario, London, Ontario, Canada N6A $3 K 7$
}

This is the authors' manuscript of the work published in final form as:

P. Fraser Johnson, Robert D. Klassen, Michiel R. Leenders, Amrou Awaysheh, (2007) "Selection of planned supply initiatives: the role of senior management expertise", International Journal of Operations \& Production Management, Vol. 27 Issue: 12, pp.1280-1302, https://doi.org/10.1108/01443570710835624

* Corresponding author

Richard Ivey School of Business, The University of Western Ontario, London, Ontario, Canada N6A $3 K 7$

email: fjohnson@ivey.uwo.ca, tel.: (519)661-3219, fax: (519)661-3485 


\title{
Selection of Planned Supply Initiatives: The Role of Senior Management Expertise
}

\begin{abstract}
Purpose - The drivers that influence the selection of particular supply initiatives by firms is of major interest to both practitioners and academics, as choices indicate priorities for resources, potential performance gaps and needs for future research. Moreover, theory indicates that senior management expertise and firm-level resources might influence the likelihood of selecting particular initiatives.
\end{abstract}

Methodology / approach - A synthesis of the literature supported our development of a fivedimensional framework of major supply initiatives. Logistic regression was conducted with data from a survey of chief purchasing officers at large North American firms. The impact of firmlevel resources and senior management expertise, including background and experience, was assessed for the selection of supply initiatives.

Findings - After controlling for general industry-level factors, both firm resources and senior management expertise were found to systematically affect the likelihood of a firm planning to pursue particular initiatives. First, hiring senior management from outside the firm decreased the likelihood that network-based initiatives were planned, while senior management who last worked in supply found to be negatively related to planned supply strategy initiatives. Second, firms with greater use of e-business technologies favored additional investment in supply networks.

Research limitations / implications - This research focused on large firms in developed countries, and additional research is needed to explore the generalizability to small- and mediumsized enterprises and less developed countries is needed. Moreover, additional work is needed to explore trade-offs between planned and emergent initiatives, as only the former were empirically assessed.

Practical implications - Senior management expertise has received relatively little attention in prior research, yet was found to be a significant factor influencing strategic, process and network-related supply initiatives. Moreover, the framework of supply initiatives provides a basis for assessing and benchmarking firm-level supply chain strategy and investment patterns. Finally, empirical evidence emerged that both firm- and individual-level factors influenced the probability of selecting particular initiatives.

Key Words - Supply management; purchasing; resource-based view; transaction cost economics. 


\section{Introduction}

Senior managers are continually searching for and identifying new opportunities to reshape and improve the performance of the supply management function in their firms. For example, initiatives include building new supply management strategies and practices, such as partnering and information sharing with key suppliers, adopting new e-business technologies, and implementing supplier development programs (e.g., Nelson, 2004). However, supply initiatives like other strategic and operational changes are constrained, in part, by a firm's history, resources and capabilities (Cousins, 2005). For this reason, research in supply management and in supply chain management has focused on industry- or firm-level factors for planned initiatives (e.g., Power and Simon, 2004).

Much less attention has focused on the how the characteristics of individual supply managers might shape the strategic direction that a firm pursues, as reflected in their plans for major strategic initiatives. Senior supply managers motivate strategic reviews (Watts et al., 1992), influence the gathering of competitive data and benchmarking (Carr and Smeltzer, 1999), direct program development (Trent and Monczka, 1994), reward strong performers (Prahinski and Benton, 2004), and ultimately control the allocation of resources (Salancik and Pfeffer, 1977). Thus, decision-making by individual managers (Knott, 2001) - and their individual expertise might be expected to be pivotal as they identify, prioritize and implement new initiatives.

In order to assess the general directions that firms are moving to improve supply management, it is essential to have a generalizable framework to categorize initiatives. Ideally, such a framework is derived from theory and not tightly bound to specific technologies, projects and programs that are currently receiving management attention. Moreover, with new developments in the area of supply management, such as information technology and 
globalization, an accounting of planned initiatives provides a useful indication for where the supply field is heading, as defined by ongoing investment.

The remainder of this paper is organized as follows. First, as a basis for assessing the role of supply managers' expertise, the following section draws from the supply, strategy and transaction cost economics literatures to develop a multi-dimensional framework of supply initiatives. Four sets of hypotheses also are presented to delineate the expected relationships between supply initiatives, and firm- and individual-level factors. Next, the survey methodology and construct measurement are detailed. In the final sections, the results are presented, and the implications for theory and managerial practice are discussed.

\section{Theoretical Development}

Examining the relationship between senior management's expertise and planned supply initiatives provides a window through which to examine the strategy formulation process, as well as offering some indication of where the supply function is headed over the near term. As a first step, it is important for research to abstract beyond particular, individual projects and technologies, such as RFID. Instead, the emphasis must be on identifying broader theoretical groupings (i.e., categorization) that align with underlying supply capabilities and resources.

Unfortunately, developing a framework that defines and categorizes supply initiatives is both challenging and fraught with trade-offs. If empirically derived, any framework is unlikely to capture promising new practices that are just beginning to emerge. Pragmatically, methods such as exploratory factor analysis of survey data also do not necessarily isolate clear, meaningful, coherent groupings (Hair et al., 1995), and these groupings might change rapidly over time as new technologies emerge or the competitive marketplace evolves. 
In contrast, if theoretically derived, earlier research literature potentially can be leveraged to underpin a framework that has clearly delineated categories with greater longevity. For example, such typologies have emerged in service management (e.g., Cook et al., 1999) and operations strategy (e.g., Bozarth and McDermott, 1998). However, it is still possible that truly groundbreaking areas are overlooked. Additionally, for either approach, the researcher must wrestle with the degree of abstraction versus specificity, which in turn translates into a small or large number of constructs.

\section{Framework of Supply Initiatives}

Over the last several years, research on supply initiatives has emphasized empirically-derived classifications, with at least three separate research efforts aimed at identifying major new supply initiatives. In their study of purchasing and corporate trends in large North American companies, Carter and Narasimhan (1996) used exploratory factor analysis to empirically identify eight purchasing and supply management future directions factors. Similarly, Trent and Monczka (1998) surveyed senior supply managers and identified seven changes and trends affecting purchasing. Finally, in their 10-year forecast of purchasing and supply management, Carter et al. (2000) identified 18 issues using a combination of executive interviews and surveys. Unfortunately, the supply initiatives identified from these three papers generated a large number of categories of supply initiatives that lacked a common terminology to guide future research.

Given the relative dearth of theoretically derived schemes, this study adopted a different approach, namely combining previous supply management research with three well-established literature streams that underpin much of our understanding of supply management: transaction cost economics (Williamson, 1991); the resource-based view (Barney, 1991); and social network 
theory (Wasserman and Faust, 1994). The framework that emerges, depicted in Figure 1, identifies five dimensions: strategy, processes, network, organization and measurement. Table 1 shows how earlier research by Carter and Narasimhan (1996), Trent and Monczka (1998) and Carter et al. (2000) maps on to the five dimensions. In addition, Figure 1 is strongly related to the framework developed by Cooper et al. (1997) that was intended to guide supply chain decisionmaking and research. Their framework highlighted three key elements: business processes, management components and supply chain structure.

Transaction cost economics (TCE) has been used increasingly by researchers to study supply management issues (e.g., Hobbs, 1996). The two most relevant areas are related to strategy and processes. Supply strategy encompasses the selection of governance structure (market or hierarchy) and the degree of vertical integration with suppliers (e.g., Bensaou, 1997; Stump and Heide, 1996). Transaction costs, including efficiency of processes between the firm and its suppliers must be congruent with the governance structure selected (Grover and Malhotra, 2003).

In essence, supply chain structure in the Cooper et al. (1997) framework maps onto the strategy category, which is consistently highlighted as critical in current research (e.g., Mills et al., 2004) and textbooks (e.g., Leenders et al., 2006). In a highly competitive global marketplace, supply must be forward looking, innovative, and have the ability to effectively plan for and respond to dynamic business environments. A number of studies have highlighted the need to link such strategic supply initiatives with broader corporate strategy (e.g., Watts et al., 1992; Arnold et al., 1999; Cousins, 2005). In addition, recent research has found that firms are increasingly use technology as part of their strategic sourcing activities, commonly referred to as e-sourcing (Johnson and Klassen, 2005), in efforts to reduce costs and improve speed. 
Supply processes denote the procedures and means by which supply chain activities are undertaken, similar to the business processes described by Cooper et al. (1997). As suggested by TCE, organizations place a strong emphasis on managing supply processes, both in terms of efficiency and effectiveness. For example, by shifting resources from tactical buying to strategic sourcing, firms have invested in technology and adopted processes that reduce transaction costs (Boyer and Olson, 2002; Kaufmann and Carter, 2004).

While the resource based view (RBV) is a widely applied perspective for studying firm strategy, it also has clear implications for internal firm structure. Firms must also have internal organizational structures, such as interfunctional teams. Furthermore, firms can create competitive advantage when they are successful in creating linkages with critical suppliers that successfully exclude competitors from forming the same relationships (Rungtusanatham et al., 2003). The ability to be able to assess opportunities implies the existence of appropriate measurement and evaluation systems to identify and assess opportunities for new supply sources, relationships, improvement prospects, and performance advantages (Mol, 2003).

Thus, the management element in the Cooper et al. (1997) framework is bisected into two distinct dimensions, consistent with defining the boundary of the firm in TCE. Consequently, two distinct types of change emerge, with internal relationships being defined separately and distinctly from supply performance measurement. Measurement includes evaluating and monitoring the performance of the supply function and key suppliers (Staughton and Johnston, 2005; Bititci et al., 2005). Organizations are using tools such as cost management models, balanced scorecards and benchmarking to identify gaps in performance and opportunities for improvement (Kennerley and Neely, 2003; De Toni and Tonchia, 2001; Nelson, 2004). A traditional area of interest to supply practitioners and academics has been total cost of ownership. 
The substantial body of supply literature on this subject has identified methodologies for determining all the cost elements of a purchase decision and opportunities to use such information for achieving lower costs or improved value (e.g., Ellram, 1994). More recently, the use of Six Sigma methodologies has become increasingly popular as a disciplined approach to identifying and eliminating waste and creating lean supply chains (Polkin, 1999; Hines et al., 2005).

Social network theory, i.e., the examination of interactions between individuals and their relational ties (Wasserman and Faust, 1994), implies that firms must be capable of not only successfully managing their internal organization (Leenders and Johnson, 2000), but also a wide range of supply network relationships (Harland et al., 2004). Relationships between supply chain members encompass both the structure of the supply chain and the form of linkages between different actors and organizations along the supply chain. As noted earlier, the classic line of demarcation has been the firm boundary, with relationships either being internal (e.g., between different groups or functional areas) or external to the firm (Lamming et al., 2000). Previous research on internal relationships has examined the roles and responsibilities of the supply function: its structure, the use of cross-functional teams and the reporting line of the chief purchasing officer (CPO) (Rozemeijer, 2000; Johnson and Leenders, 2004). In contrast, relationships embodied in the supply network include external inter-organizational relationships that extend upstream and downstream of the focal firm (Mills et al., 2004).

\section{Individual- and Firm-Level Factors}

Much of the research in supply management uses the firm as the unit of analysis, focusing on differences at the industry- or firm-level. Largely absent from the literature is a detailed 
consideration of how individual-level factors, such as expertise, might influence the development of supply competitiveness, as evidenced by the selection of planned supply initiatives.

\section{$\underline{\text { Senior Management Expertise }}$}

It is widely recognized that individual managers play a critical role in identifying, planning and implementing change in organizations (Salancik and Pfeffer, 1977). This can occur through a senior supply manager's ability to set vision, motivate change, allocate resources and reward action and performance. For example, previous research has found that individual managers can influence the strategy formulation process. Barnes (2002) found that manufacturing strategy is formed in a complex process involving a combination of deliberate and emergent actions and decisions. Moreover, the degree and form of planned initiatives is linked to the individual's background, which serve as both a filter for all possible initiatives and an enabler for improving the likelihood of success for any planned initiative.

To date, the characteristics of the individual senior manager in supply initiatives has received very little attention. Earlier research indicates that individuals can represent a resource for building capabilities that provide competitive advantage (Castanias and Helfat, 1991; Ficklestein and Hambrick, 1996). For example, CPOs in large companies have a range of experience and diverse backgrounds; Johnson et al. (1999) found that 20 percent of responding organizations had recruited their CPO from outside the company and 40 percent of the externally hired CPOs had backgrounds only in supply. In contrast, one-third of the CPOs promoted internally had no supply experience at all. More recent research found that 36 percent of CPOs in responding firms had most recently worked in a function other than supply before becoming CPO (Johnson and Leenders, 2004). In addition, CPOs that have worked in supply for their entire careers have a 
narrower range of supply chain responsibilities compared to CPOs with either mixed work experience or a non-supply experience (Johnson et al., 1998).

Collectively, CPO expertise must capture depth of their experience, both inside and outside purchasing, and the scope of their exposure across a variety of functions and firms. For example, a narrower range of responsibilities may also suggest a tighter focus on process-related initiatives rather than broader changes to the supply network. Consequently, we proposed the following:

Hypothesis la: CPOs whose previous position was outside the supply function are more likely to pursue initiatives related to supply networks.

Hypothesis 1b: CPOs whose previous position was inside the supply function are more likely to pursue initiatives related to supply processes.

As previously stated, research has found that a significant percentage of CPOs are recruited from outside the firm (Johnson et al., 1999). Based on earlier research, (e.g., McCann, 2004), such individuals may be more inclined to challenge the status quo with respect to the boundary of the firm, and therefore its strategy, and identify potential initiatives aimed at reducing transaction costs. Thus,

Hypothesis 2a: Externally recruited CPOs are more likely to pursue initiatives related to supply strategy.

Haytko (2004) found that relationships at an individual level can influence relationships between firms. The internally recruited CPO group would likely be more familiar with the firm's supply base and be in a better position to leverage existing relationships with suppliers, compared to the externally recruited group. As a result, the internally recruited CPO group would tend to focus on supply network initiatives, suggesting a relational perspective. Consequently we propose, 
Hypothesis 2b: Internally recruited CPOs are more likely to pursue initiatives related to supply networks.

\section{$\underline{\text { Firm Resources }}$}

In addition to individual-level factors, such as expertise, the research literature points to a wide variety of firm-level resources that might influence supply initiatives. Given that firm resources and existing capabilities are generally considered to be two critical levers for supply managers (Carr and Pearson, 2002), three specific factors received particular attention: firm size, the strategic nature of purchasing and current use of e-business technology. Clearly, these resources are not meant to be exhaustive, but rather indicative of resources and capabilities that might foster or hinder planned initiatives.

E-business technologies evolved rapidly over the last decade come in a variety of forms, some well-established and others newly developed. Under TCE, e-business technologies represent one mechanism to manage boundary spanning activities in the supply chain. A number

of e-business technologies focus specifically on reducing coordination costs (Subramani, 2004) and may also represent an asset-specific investment, increasing the potential for opportunistic behavior by one party (Zaheer and Venkatraman, 1994). For example, some of these technologies represent streamlining and automating business processes among supply chain partners as a means of reducing transaction costs (Choudhury et al., 1998), such as electronic requests for quotations (eRFQ), EDI and electronic transmission of purchase orders (ePO) (Subramani, 2004). Firms have been actively pursuing opportunities to automate supply chain processes to reduce transaction costs by reducing administrative costs and reducing the cycle 
time from need recognition to receipt of the purchased good or service (Johnson and Leenders, 2004).

Thus, TCE points to one form of e-business technology that seeks to improve existing interfirm business processes, thereby reducing transaction costs and transaction risk, labeled transactional technologies. Consequently, it is expected that use of transactional e-business technologies will be initiatives related to processes:

Hypothesis 3a: As transactional e-business technology use increases, firms will be more likely to pursue initiatives related to supply processes.

However, e-business technologies can also offer new approaches to sourcing and collaboration with supply chain partners, which can be exploited to create competitive advantage (Barua et al., 2004). Potential benefits of e-business technology use include the ability to share information in a timely manner as means of reducing transaction risk, in areas such as holding inventory, freight and administration (Srinivasan et al., 1994; Mukhopadhyay et al., 1995). Relational-specific investments, such as private exchanges between buyers and key suppliers, create more value than non-specialized generic assets and can be an important source of competitive advantage (Dyer and Singh, 1998). Consequently, e-business technologies used to support collaboration are labeled relational technologies. In contrast to transactional e-business technologies, it is expected that relational e-business technologies are positively related to the adoption of supply network initiatives.

Hypothesis 3b: As relational e-business technology use increases, firms will be more likely to pursue supply initiatives related to supply networks.

$\underline{\text { Industry Sector }}$ 
Industry context influences supply management in a number of important areas, including new product development, quality management practices, supply strategy and the use of purchasing teams (Swink, 1998; Dow et al., 1999; Johnson et al., 2002). Discrete goods manufacturers, such as companies in the consumer goods and automotive sectors, face a number of dynamic and product specific pressures that affect their supply network, which are less likely to occur in processing industries, such as oil and gas. In contrast to firms in the manufacturing sector, service firms spend significantly less on outside suppliers, although significant amounts can be spent on capital equipment in some service industries such as transportation and telecommunications (Heberling et al., 1992). Consequently, the industry sector has been included as a set of control variables.

\section{Research Design}

\section{The Sample}

A survey instrument was developed to examine the relationships between individual expertise, firm resources, and industry sector using a firm-level unit of analysis. The target population for this study was comprised of large manufacturing and services firms in the U.S. and Canada. The Title 1 membership list of the Institute of Supply Management (ISM) and the CAPS Research membership directory were used to identify U.S. respondents for firms on the Fortune 1000 list, excluding firms in the retail and wholesale sectors. The membership database of the Purchasing Management Association of Canada (PMAC) was used to identify Canadian respondents for firms on the Financial Post 100 list, also excluding firms in the retail and wholesale sectors.

In order to reduce the potential for single-respondent bias, the research focused on high-level managers who tend to be more reliable sources of information than lower-level managers 
(Philips, 1981). At each organization, the CPO was targeted because the individual position would be most familiar with the major supply initiatives at his or her firm. The title of the respondent sought was primarily vice president or director of purchasing or supply management. The survey was nine pages in length and typically required 20 to 30 minutes to complete. It was pre-tested on a group of five CPOs and two academics. This group was asked to review the questionnaire for structure, readability, ambiguity and completeness, and the survey instrument was refined based on their feedback.

In an effort to increase the response rate, a modified version of the Dillman (2000) methodology was followed. In October 2003, questionnaires were mailed along with a cover letter and stamped return envelope to 658 organizations. From the initial sample frame of 658,18 were dropped because they had been inadvertently duplicated in the database, ceased operation or moved to a new location. Consequently, the effective sample frame was 640 organizations, consisting of 562 U.S. and 78 Canadian firms.

Two weeks after the initial mailing, reminder emails were sent to all non-respondents; fax was used for respondents where an email address could not be obtained. After four weeks, a second mailing of the survey was undertaken to non-respondents. Finally, two weeks later a reminder telephone call was made to each non-respondent.

To encourage the widest possible participation, respondents were given three options for the completing and returning the survey: mail, in the stamped return envelope; fax; and Internet (web-based questionnaire). Nearly three-quarters of the responses were received via mail. Of the 640 targeted firms, 284 completed surveys were returned, representing a response rate of 44 percent. The distribution of the sample, with respect to sales, is provided in Table 2. 
Non-response bias was tested by comparing the responses of early and late waves of returned surveys (Armstrong and Overton, 1977). No significant differences were identified. Additionally, tests were performed to determine if the distribution of the respondent sample differed from the targeted population (Lambert and Harrington, 1990) using several descriptive characteristics: industry sector, firm size and CPO title. No evidence was found that the respondents were not representative.

\section{Planned Supply Initiatives}

To assess planned supply initiatives using a survey instrument, at least two general approaches are possible. First, potential respondents might be presented a list of possible initiatives generated from prior research and pilot testing (e.g., Carter and Narasimhan, 1996; Trent and Monczka, 1998; Carter et al., 2000). Respondents then indicate the likelihood that particular initiatives will be adopted. Alternatively, an open-ended question offers the potential for a broader range of responses, with the primary challenge being the consistent categorization of each response individually. Given the additional effort required on the part of the respondent to write in their reply, it is also to be expected that only the top few initiatives will be listed and that priorities will become clearer.

For this research, the latter approach was employed to ensure the widest variety. Respondents were asked the following open-ended question: By the year 2008, in your firm, what major innovation/change in the purchasing/supply area do you plan to implement to contribute to organizational effectiveness? A total of 199 firms responded to this question, with many respondents listing several planned initiatives. Item-level tests for non-response bias between the firms that responded to this question and firms that did not report planned initiatives showed no 
significant differences. However, as noted at the beginning of this paper, the emphasis was not to simply to identify which initiatives firms plan to implement, but rather to explore the pattern linking individual-level senior management factors with the selection of particular supply initiatives for their firms.

Coding of the data was performed independently by two experienced supply researchers using the five theoretically identified supply initiatives categories: supply strategy, supply processes, measurement, internal organization relationship and supply network relationship. The two data coders agreed on 82 percent of the responses, suggesting high levels of intercoder reliability (Weber, 1990). Any areas of disagreement were assessed and discussed until consensus was achieved by the two coders.

\section{Senior Management Expertise}

Individual senior management expertise was captured using three self-reported measures, specifically focusing on the individual in the CPO position. The first measure asked the respondent to indicate her or his work experience immediately prior to becoming $\mathrm{CPO}$ in the current firm. The second asked if the respondent had been recruited from another firm directly into the $\mathrm{CPO}$ position. In cases were a $\mathrm{CPO}$ was recruited from outside the company, the majority of respondents indicated that they had most recently been in a supply position with their previous employer. For modeling purposes, CPOs recruited from inside the company whose previous position was in supply were used as the reference group; two dichotomous variables were used (Figure 2). In addition, respondents reported the number of years that she or he had worked in supply as an indicator of experience; a logarithmic transformation was used in subsequent analysis. Of the 199 respondents, complete data was available for 192 firms. A 
further nine observations were subsequently dropped as outliers after assessing a casewise diagnostic plot from the logistic regression, yielding 183 observations for the logistic regression model estimation.

\section{Firm Resources}

Three variables were included in the model to assess the role of firm level resources. Firm sales was used to measure firm size and the strategic nature of supply was captured by a self-reported measure of CPO title. CPO title included three dichotomous variables - director, vice president and other (e.g., manager and general manager) - as an indicator of the strategic nature of supply at the firm. For modeling purposed, the other group was used as the reference group. Also included in the model were variable for e-business technology use.

\section{$\underline{\text { E-Business Technology Use }}$}

Based on the breadth of traditional and new e-business technologies noted earlier, a dozen forms were identified from the literature. While it is undoubtedly possible to identify other forms, this list represented a workable set that spanned many applications rather than a complete inventory of all possible technologies. Respondents were requested to report their firm's level of each of ebusiness technology on a five-point Likert scale $(1=$ none to $5=$ extensive $)$.

As a first step toward identifying a taxonomy of e-business technologies, exploratory factor analysis (principal components analysis with varimax rotation) was used to analyze common pattern of usage across the 12 forms of e-business technologies. Both a scree plot and eigenvalue criterion (greater than one) supported the extraction of three factors. All items loaded on one 
factor above the recommended level of 0.50 (Hair et al., 1995). Table 3 provides the results for the factor analysis of e-business technology usage (see also Johnson et al., forthcoming).

Overall, a three dimensional construct was supported. The first factor was labeled "dyadic coordination" and included electronic / online purchase order system, electronic / online supplier catalogue, real-time linkage with suppliers and electronic data interchange. The reliability coefficient (Cronbach's $\alpha$ ) for the dyadic coordination factor was 0.77 , above the threshold recommended for exploratory research (Nunnally and Berstein, 1994). The second factor, labeled "price determination", consisted of the items online bidding / tendering, online reverse auction / e-auction, industry-sponsored e-marketplaces and public e-marketplaces $(\alpha=0.74)$. The third factor, termed "private exchange," consisted of the items related to extranets and exchanges $(\alpha=$ $0.70)$.

\section{Industry Sector}

As control variables, firms were classified into one of five industry groups (i.e., sectors) based on their two-digit SIC code: discrete goods manufacturing, process manufacturing, resource, high capital-intensive-service or low capital-intensive service firms. While a finer-grained

categorization is possible, this level allowed a reasonable assessment of broadly-based industry differences in planned future initiatives. Firms in the discrete goods manufacturing group were from the furniture, leather, fabricated metal, machinery, electronic equipment, transportation equipment, instruments and miscellaneous manufacturing sectors. Firms classified in the process industries group were from the primary metal, lumber, rubber and stone industries. Metal, coal, oil and gas, mining and heavy construction were all part of resource industries. 
Capital intensity is a measure relevant to supply management, and this ratio was used here to identify two broad groups of service industries. To identify industries that were high- versus lowcapital intensive, the ratio of net sales to property, plant and equipment was estimated for every firm in these SIC codes from Compustat $(2003)(n=1,858)$. Next, the average was calculated for each of the 15 service industries, and then sorted, low to high. A break-point was established at 3.0 for high vs. low capital-intensive service industries. Based on this analysis, the high capital-intensive group of services included all respondents in the railroad transportation, air transportation, communications, electricity and gas utilities, eating and drinking and automotive repair industries. In contrast, respondents in the motor freight transportation, transportation services, credit institutions, insurance carriers, insurance agents and brokers, hotels, business services, motion pictures and engineering, accounting and research sectors were placed in the low capital-intensive group. For modeling purposes, the reference group was process manufacturing firms; four dichotomous variables were used.

\section{Empirical Results}

\section{Planned Initiatives}

Data coding produced 397 separate initiatives from the 199 firms that reported initiatives, representing an average of two planned initiatives per firm. Ninety-four percent of the respondents reported one to three initiatives and the most frequently identified planned initiative was supply process, identified by two-thirds of the respondents. Respondents indicated that investments in information technology, such as e-procurement and ERP systems would reduce or eliminate manual systems, lower transaction costs and increase response times and speed. 
Internal organization and supply strategy were both identified by 40 percent of the respondents. This finding supports previous research which has documented that large firms make frequent changes to the organizational structure and roles and responsibilities of the supply function (Johnson et al., 1998). Among the respondents indicating planned initiatives in supply strategy were plans for increased global sourcing and greater use of e-sourcing tools, such as reverse auctions. Measurement was identified by 31 percent of the respondents, who indicated future plans for using total cost of ownership and supply metrics and scorecards. Finally, supply network initiatives and changes were identified by 22 percent of respondents.

\section{Drivers of Planned Initiatives}

Logistic regression was used to assess the relationships between industry sector, firm resources and individual expertise with the five categories of future initiatives. All dependent variables were dichotomous, with a firm either reporting a planned initiative within each category, or not. Thus, for each model, industry sector, firm resources and individual expertise variables were assessed for their effect on the likelihood that a firm planned to pursue that form of initiative. A similar model has been used for adoption of new technology (e.g., Sohol et al., 2001; Co et al., 1998). In addition, the estimate of each coefficient is the odds-ratio, and can be quantitatively interpreted (i.e., odds-ratio $=\exp \left(\mathrm{B}_{\mathrm{i}}\right)$ ). Finally, the combined general contribution of each of the three levels (i.e., industry, firm or individual) could be assessed by evaluating the significance of the incremental $\chi^{2}$, which is analogous to the incremental $\mathrm{R}^{2}$ in hierarchical linear regression.

The correlation matrix for the independent variables is presented in Table 4, and results of the logistic regression analysis are presented in Table 5. 


\section{$\underline{\text { Senior Management Expertise }}$}

Three of the five models indicated that senior management expertise was a significant factor in planned initiatives (Table 5). Contrary to H1a, the logistic regression highlighted a strong negative relationship between CPOs who last worked outside supply, and plans to implement supply network initiatives. Conversely, CPOs who last worked in a supply position were 3.9 times (i.e., $1 / e^{-1.35}$ ) more likely to pursue supply network initiatives compared to those whose previous position was outside supply. No support was found for H1b to suggest a relationship between CPOs who last worked inside the supply function and the implementation of supply process initiatives.

Some support was also found for $\mathrm{H} 2 \mathrm{a}(\mathrm{p} \leq 0.10)$ as the results indicate externally recruited CPOs were more likely to pursue supply initiatives related to supply strategy. Meanwhile, strong support was found for $\mathrm{H} 2 \mathrm{~b}$, with the logistic regression model indicating that internally recruited CPOs were much more likely to pursue initiatives related to supply networks $(\mathrm{p} \leq 0.01)$. More specifically, CPOs recruited from inside the firm were 5.2 times more likely to focus on supply network initiatives compared to CPOs recruited from outside the company.

Surprisingly, years of experience in supply was found to be negatively related to planned supply strategy initiatives $(\mathrm{p} \leq 0.05)$, i.e., CPOs with less experience were more likely pursue to strategy initiatives. The negative coefficient $(B=-0.58 ; p<0.01)$ indicates for every ten years less of experience, the $\mathrm{CPO}$ was 1.78 times more likely to be planning to undertake supply strategy initiatives.

\section{$\underline{\text { Firm Resources }}$}


Contrary to H3a, dyadic coordination negatively influenced the adoption of supply process initiatives (Table $5 ; \mathrm{p} \leq 0.05$ ). In addition, dyadic coordination also significantly influenced plans to adopt supply network initiatives $(\mathrm{p} \leq 0.01)$. The odds ratio indicates that as firms increasingly use dyadic coordination they were less likely to report undertaking supply process initiatives, and more likely to pursue supply network initiatives. In addition, greater use of private exchange or less extensive use of price determination influenced the likelihood that supply network initiatives were planned ( $\mathrm{p} \leq 0.10)$, counter to H3b. Finally, sales was significantly related only to planned initiatives for measurement. It is possible that the challenges inherent in controlling, coordinating and improving very large organizations require the more frequent investment in assessing ongoing supply operations.

\section{Discussion}

Drawing on three streams of literature, transaction cost economics, the resource based view and social network theory, a theoretically derived framework of five major dimensions was used to categorize and assess planned supply initiatives. Strong linkages were found between firm- and individual-level factors and these initiatives. Specifically, empirical tests found that senior management expertise had a more significant influence on planned initiatives than did industry sector in determining the selection of planned initiatives. For four of the five dimensions, expertise explained a greater proportion of the variance than industry sector. Consequently, a major contribution of this research is an improved understanding of the drivers of planned initiatives. The following section expands on the implications of the research and its limitations.

Influence of Industry Sector, Firm Resources and Senior Management Expertise 
An important finding of this research was the significant influence of individual factors on planned supply initiatives. These findings suggest that planned initiatives tend to be influenced substantially by the individual CPO's expertise, more so than contingent factors related to the industry. Consequently, while considerable research has attempted to examine differences in supply strategies on the basis of industry sector (e.g., Rozemeijer et al., 2003), it would appear that the expertise of senior supply executives represents an important explanatory variable.

The findings that CPOs who are recruited from outside the company were more inclined to focus on initiatives related to supply strategy and measurement, while those hired from inside the company are more likely to focus on supply process and supply network initiatives, points toward a different orientation among the two groups. Specifically, the externally recruited group with relatively fewer years of supply experience (i.e., fewer years in purchasing) was focused on the development of strategic sourcing capabilities, representing a transactional orientation (TCE). Conversely, internally recruited CPOs, who were promoted from within the supply organization were more likely to pursue initiatives related to supply network relationships. This supports earlier research findings that individuals can represent a resource for building capabilities that provide competitive advantage (Castanias and Helfat, 1991; Ficklestein and Hambrick, 1996).

Our finding that the externally recruited CPO group was more inclined to plan to implement supply strategy and measurement initiatives indicates that, for at least some organizations, a fresh perspective can be useful in identifying opportunities. A new CPO from another organization may not be as easily influenced by past practice and may be more willing to explore previously unrecognized or ignored opportunities in these areas. Perhaps, by leveraging earlier experience, such individuals may be more inclined to challenge the status quo with respect to the boundary of the firm, and therefore its strategy, and identify potential initiatives aimed at 
reducing transaction costs (McCann, 2004). Alternatively, it is possible that new CPOs were hired based on previous experience or capabilities. Whether CPOs were screened for or specifically recruited to focus on specific supply initiatives represents an opportunity for future research.

In contrast, hiring a $\mathrm{CPO}$ from within the existing supply ranks may signal satisfaction with the status quo related to personal involvement with prior changes, and these individuals are likely to be less inclined to make dramatic changes (Hambrick, 1984). Consequently, the internally recruited group is more concerned with supply network initiatives, and is consistent with previous research that has found that relationships at an individual level can influence relationships between firms (Haytko, 2004). As a result, internally recruited CPOs were more inclined to build relationships with suppliers as a means of enhancing their supply networks, as suggested in the social network theory, supported by a pre-existing familiarity with supply chain partners and their roles.

This research also confirmed the influence of supply's strategic nature on supply network initiatives. Specifically, the higher the reporting level of the CPO in the organization the more likely CPOs were to pursue supply network initiatives.

Given the emphasis that many of the respondents placed on using information technology and e-commerce for supply strategy and supply process initiatives, it is noteworthy that while the dyadic coordination variable did influence supply network initiatives, it negatively influenced the adoption of supply process initiatives. It may be possible that the adoption levels of e-business technologies at most companies is still too low to influence future initiatives.

Lastly, the findings also indicate differences among industry groups. Respondents in process industries are more likely to plan initiatives in supply strategy (e.g., transactional) compared to 
respondents in discrete goods manufacturing and high capital intensive services industries. Similarly, firms from the discrete manufacturing sector were less likely to plan to implement initiatives in internal organization than firms in the process sector. One possible explanation for these findings is that firms in discrete goods have already begun work on supply strategy and internal organizational improvements, and are now focusing on other areas. It could also be possible that there is a progression among initiatives, possibly starting with supply process (e.g., transactional) and progressing to supply network initiatives. Alternatively, competitive factors could also influence prioritization of such initiatives. Future research could shed light on the reasons why firms in different industry sectors focus on specific supply initiatives.

\section{Planned Initiatives}

Findings indicated that the majority of CPOs plan to implement initiatives related to supply processes. These initiatives are focused on reducing transaction costs and improving speed, largely through investments in e-procurement and ERP systems, as suggested by TCE. Following the shake-out in the e-commerce sector in 2000, many companies took a cautious approach to investments in information systems.

In addition to a focus on supply process improvements, there was also considerable interest by CPOs in initiatives that involved internal organization and supply strategy, representing development of strategic capabilities and organizational processes as proposed by RBV. Several responses referred to the use of e-sourcing tools, such as e-auctions, and were consistent with the theme of investing in new technology. However, other responses identified global sourcing, suggesting that many CPOs see opportunities to internationalize supply in an effort to support organizational goals and strategies. 
Our finding, that 40 percent of CPOs plan major internal organization initiatives, is consistent with previous research that large organizations make frequent changes to their supply organizational structures and to the responsibilities of the supply function (Johnson et al., 1998). Ultimately, many supply managers can look forward to organizational change, resulting in the need to adapt to new organizational structures, reporting lines and roles and responsibilities. In such an environment, effective supply managers need not only be good buyers and competent managers, but also effective in leading change as responsibilities are both added and subtracted from the supply organization.

An additional finding was the relatively small number of responses that identified planned initiatives related to supply network structure. The academic supply chain literature suggests the importance of a supply chain orientation. However, our findings suggest limited CPO concern with end-to-end supply network structure, and more interest in supply strategy, supply processes, measurement and internal organizational relationships (e.g., TCE and RBV).

\section{Limitations}

This research has several limitations. First, the sample, while large, is limited to large North American firms. Additional research can explore initiatives and changes among European or Asian firms, or at small and medium size enterprises (SMEs). Second, additional work is needed to explore trade-offs between planned and emergent initiatives, as only the former were empirically assessed.

\section{Conclusion and Opportunities for Research}


The objectives of this research were to understand what initiatives large North American firms are planning to implement and how industry sector, firm resources and individual expertise influenced these plans. Drawing on three primary streams of literature, transaction cost economics, the resource based view and social network theory, a theoretically derived framework was used to assess supply initiatives planned by CPOs in large North American firms. Empirical tests found that individual expertise had a more significant influence on planned initiatives than did industry sector in determining the selection of planned initiatives. Consequently, an improved understanding of the drivers of planned initiatives represents a major contribution of this research.

The majority of the respondents in the study planned to implement one to three initiatives, with supply process improvements representing the most frequently planned initiative. While the findings did indicate some differences at the industry and firm level, the most significant differences were at the individual level.

Findings from this research suggest several opportunities for future research. While this research was largely exploratory, it does provide a framework for surveying supply executives using the five categories of supply initiatives. A second opportunity is to conduct a longitudinal study that identifies planned initiatives and follows up to measure the extent to which planned changes were carried out. Such research could investigate the extent to which factors within the firm (e.g., corporate strategy) and outside the firm (e.g., competitive factors) influence supply initiatives.

A significant finding in our study was that individual expertise was an important predictor of future initiatives and changes. Consequently, a third opportunity for future research concerns the background of CPOs. Specifically, how are CPOs selected and to what extent are supply 
initiatives influenced by their personal background or mandated by the executive to whom they report? Case-based research would be the appropriate methodology to explore this research issue.

\section{References}

Armstrong, J.C. and Overton, T.S. (1977). "Estimating nonresponse bias in mail surveys," Journal of Marketing Research, Vol. 14 No. 3, pp. 396-402.

Arnold, U., et al. (1999). A multi-country study of strategic topics in purchasing and supply management, CAPS Research: Tempe, Arizona.

Barney, J. (1991). "Firm resources and sustained competitive advantage," Journal of Management, Vol. 17 No. 1, pp. 99-120.

Barnes, D. (2002). "The complexities of the manufacturing strategy formation process in practice," International Journal of Operations \& Production Management, Vol. 22 No. 10, pp. 1090-1111.

Barua, A.; Konana, P.; Whinston, A.B.; Yin, F. (2004). "An empirical investigation of newenabled business value," MIS Quarterly Vol. 28 No. 4, pp. 585-620.

Bensaou, M. (1997). "Interorganizational cooperation: the role of information technology an empirical comparison of US and Japanese supplier relations," Information Systems Research, Vol. 8 No. 2, pp. 107-124.

Bititci, U.S., Mendibil, K., Martinez, V. and Albores, P. (2005). "Measuring and managing performance in extended enterprises," International Journal of Operations \& Production Management, Vol. 25 No. 3/4, pp. 333-353.

Boyer, K.K. and Olson, J.R. (2002). "Drivers of Internet purchasing success," Production and Operations Management, Vol. 11 No. 4, pp. 480-498.

Carr, A.S. and L.R. Smeltzer, "The relationship among purchasing benchmarking, strategic purchasing, firm performance and firm size," The Journal of Supply Chain Management, Vol. 35, No. 4, 1999, pp. 51-61.

Carr, A.S. and Pearson, J.N. (1999). "Strategically managed buyer-supplier relationships and performance outcomes," Journal of Operations Management, Vol. 17 No. 5, pp. 497-519.

Carter, P.J., Carter, J.R., Monczka, R.M., Straight, T. H. and Swan, A.J. (2000). "The future of purchasing and supply: a ten year forecast," The Journal of Supply Chain Management, Vol. 36 No. 1, pp. 14-26.

Carter J.R. and Narasimhan, R. (1996). "Purchasing and supply management: future directions and trends," International Journal of Purchasing and Materials Management, Vol. 32 No. 4, pp. 2-12.

Castanias, R. P. and Helfat, C. E. (1991). "Managerial resources and rents," Journal of Management, Vol.17 No. 1, pp. 155-173.

Co, H.C., Patuwo, B.E. and Hu, M.Y. (1998). "The human factor in advanced manufacturing technology adoption: an empirical analysis," International Journal of Operations \& Production Management, Vol. 18 No. 1, pp. 87-106. 
Compustat, 2003. "Compustat annual industrial file." accessed using Wharton Research Data Services, http://wrds.wharton.upenn.edu, The Wharton School of the University of Pennsylvania.

Cooper, M. C., Lambert, D.M. and Pagh, J.D. (1997). "Supply chain management: more than a new name for logistics," The International Journal of Logistics Management, Vol. 8 No. 1, pp. $1-14$.

Cousins, P.D. (2005). "The alignment of appropriate firm and supply strategies for competitive advantage," International Journal of Operations \& Production Management, Vol. 25 No. 5, pp. 403-428.

De Toni, A. and Tonchia, S. (2001). "Performance measurement systems - models, characteristics and measures," International Journal of Operations \& Production Management, Vol. 21 No. 1/2, pp. 46-71.

Dillman, D.A. (2000). Mail and internet surveys: the tailored design method, second edition, New York, NY: John Wiley and Sons.

Dow, D., Samson, D. and Ford, S. (1999). "Exploding the myth: do all quality management practices contribute to superior quality performance?" Production and Operations Management, Vol. 8 No. 1, pp. 1-27.

Dyer, J.H. and Singh, H. (1998). "The relational view: cooperative strategy and sources of interorganizational competitive advantage," Academy of Management Review, Vol. 23 No. 4, pp. 660-679.

Ellram, Lisa (1994). Total cost modeling in purchasing, CAPS Research: Tempe, AZ.

Finkelstein, S. and Hambrick, D. C. (1996). "Top-management-team tenure and organizational outcomes: the role of managerial discretion," Administrative Science Quarterly, Vol. 35 No. 3 , pp. 484-504.

Grover, V. and Malhotra, M.K. (2003). "Transaction cost framework in operations and supply chain management research: theory and measurement," Journal of Operations Management, Vol. 21 No. 4, pp. 457-473.

Hair, J.F. Jr., Anderson, R.E., Tatham, R.L. and Black, W.C. (1995). Multivariate data analysis with readings, fourth edition, Upper Saddle River, NJ: Prentice Hall.

Hambrick D. C. and Mason P. A. (1984). "Upper echelons: the organization as a reflection of its top managers," The Academy of Management Review, Vol. 9 No. 2, pp. 193-107.

Harland, C., J. Zheng, T. Johnsen and R. Laming (2004). "A conceptual model for researching the creation and operation of supply networks." British Journal of Management, Vol. 1, No. 1, p. 1-21.

Haytko D. L. (2004). "Firm-to-firm and interpersonal relationships: perspectives from advertising agency account managers," Academy of Marketing Science Journal, Vol. 32 No. 3, pp. 312-329.

Heberling, Lt. Col. M.E., Carter, J.R. and Hoagland, J.H. (1992). "An investigation of purchases by American businesses and governments," International Journal of Purchasing and Materials Management, Vol. 28 No. 4, pp. 39-45.

Henkoff, R. (1994). "Delivering the goods," Fortune, Vol. 103 No. 11, November 28, pp. 64-71.

Hines, P., Holwe, M. and Rich, N. (2004). "Learning to evolve: a review of contemporary lean thinking," International Journal of Operations \& Production Management, Vol. 24 No. 10, pp. 994-1011.

Hobbs, Jill E. (1996). “A transaction cost approach to supply chain management." Supply Chain Management, Vol. 1, No. 2, p. 15-27. 
Johnson, P.F. and Klassen, R.D. (2005). “e-Procurement,” MIT Sloan Management Review, Vol. 46 No. 2, pp. 7-10.

Johnson, P.F., Klassen, R.D., Leenders, M.R. and Fearon, H.E. (2002). "Determinants of purchasing team usage in the supply chain," Journal of Operations Management, Vol. 20 No. 1, pp. 77-89.

Johnson, P.F., Klassen, R.D., Leenders, M.R. and Awaysheh, A. (forthcoming). "Utilizing ebusiness technologies in supply chains: The impact of firm characteristics and teams determinants of purchasing team usage in the supply chain," Journal of Operations Management.

Johnson, P.F. and Leenders, M.R. (2004). Supply's organizational roles and responsibilities, Tempe, Arizona: CAPS Research.

Johnson, P.F., Leenders, M.R. and Fearon, H.E. (1999). "The chief purchasing officer: previous background and experience," European Journal of Purchasing \& Supply Management, Vol. 5 No. 2, pp. 95-101.

Johnson, P.F., Leenders, M.R. and Fearon, H.E. (1998). "The influence of organizational factors on purchasing activities," International Journal of Purchasing and Materials Management, Vol. 34 No. 3, pp. 2-11.

Kaufmann, L. and Carter, C.R. (2004). "Deciding on the mode of negotiation: to auction or not to auction electronically," The Journal of Supply Chain Management, Vol. 40 No. 2, pp. 1526.

Kennerley, M. and Neely, A. (2003). "Measuring performance in a changing business environment," International Journal of Operations \& Production Management, Vol. 23 No. 1, pp. 213-229.

Knott, A.M. (2001). “The dynamic value of hierarchy," Management Science, Vol. 47 No. 3, pp. 430-448.

Lambert, D.M. and Harrington, T.C. (1990). "Measuring non-response and bias in customer service mail surveys," Journal of Business Logistics, Vol. 11 No. 2, pp.5-25.

Lamming, R., Johnsen, T., Zheng, J. and Harland, C. (2000). "An initial classification of supply networks," International Journal of Operations \& Production Management, Vol. 20 No. 6, pp. 675-691.

Leenders, M.R., Johnson, P.F., Flynn, A.E. and Fearon, H.E. (2006). Purchasing and Supply Management, thirteenth edition, McGraw-Hill/Irwin: Burr Ridge, IL.

Lockamy, A. and McCormack, K. (2004). "Linking SCOR planning practices to supply chain performance: an exploratory study," International Journal of Operations \& Production Management, Vol. 24 No. 12, pp. 1192-1218.

McCann L. (2004). "Induced institutional innovation and transaction costs: the case of the Australian national native title tribunal," Review of Social Economy, Vol. 62 No. 1, pp. 67-82.

Mills, J., Schmitz, J. and Frizelle, G. (2004). "A strategic review of 'supply networks'," International Journal of Operations \& Production Management, Vol. 24 No. 10, pp. 10121036.

Mol, M.J. (2003). "Purchasing's strategic relevance," Journal of Purchasing \& Supply Management, Vol. 9 No. 1, pp. 43-50.

Mukhopadhyay, T.; Kekre, S.; Kalathur (1995). "Business value of information technology: a study of electronic data interchange," MIS Quarterly, Vol. 19 No. 2, pp. 137-156. 
Nelson, D.R. (2004). “How Delphi went lean,” Supply Chain Management Review, Vol. 8 No. 8, pp. 32-37.

Nunnally, J.C. and Berstein, I.H. (1994). Psychometric theory, third edition, New York: McGraw Hill.

Polkin, H. (1999). "Six sigma: what it is and how to use it," Harvard Management Update, June.

Power, D. and Simon, A. (2004). "Adoption and diffusion in technology implementation: a supply chain study," International Journal of Operations \& Production Management, Vol. 24 No. 6, pp. 566-587.

Prahinski, C. and W.C. Benton, "Supplier evaluations: communication strategies to improve supplier performance," Journal of Operations Management, Vol. 22, No. 1, 2004 pp. 39-62.

Rice, J.B. Jr. and Hoppe, R.M. (2001). "Supply chain vs. supply chain: the hype \& the reality," Supply Chain Management Review, Vol. 5 No. 5, pp. 46-54.

Rozemeijer, F. (2000). Creating corporate advantage in purchasing, Universiteits Drukkerij: Technische Universiteit Eindhoven.

Rozemeijer, F.A., van Weele, A. and Weggerman, M. (2003). "Creating corporate advantage through purchasing: toward a contingency model," Journal of Supply Chain Management, Vol. 39 No. 1, pp. 4-13.

Rungtusanatham, M., Salvador, F., Forza, C. and Choi, T.Y. (2003). "Supply chain linkages and operational performance: a resource-based-view perspective," International Journal of Operations \& Production Management, Vol. 23 No. 9, pp. 1084-1099.

Salancik, G.R. and Pfeffer, J. (1977). "Who gets power - and how they hold on to it: a strategiccontingency model of power," Organizational Dynamics, winter, pp. 3-21.

Singh, J. V. (1986). "Performance, slack, and risk taking in organizational decision making," Academy of Management Journal, Vol. 29 No. 3; pp. 562-586.

Sohal, A.S., Moss, S. and Ng, L. (2001). "Comparing IT success in manufacturing and service industries," International Journal of Operations \& Production Management, Vol. 21 No. 1/2, pp. 30-45.

Srinivasan, K.; Kekre, S.; Mukhopadhyay, T. (1994). "Impact of electronic data interchange technology on JIT shipments.” Management Science, Vol. 40 No. 10, pp. 1291-1304.

Staughton, R. and Johnston, R. (2005). "Operational performance gaps in business relationships," International Journal of Operations \& Production Management, Vol. 25 No. 3/4, pp. 320-332.

Stump, R.L. and Heide, J.B. (1996). "Controlling supplier opportunism in industrial relationships," Journal of Marketing Research, Vol. 33 No. 4, pp. 431-441.

Swink, M.L. (1998). "A tutorial on implementing concurrent engineering in new product development programs," Journal of Operations Management, Vol. 16 No. 1, pp. 103-116.

Trent, R.J. and R.M. Monczka, 1994, Effective cross-functional sourcing teams: Critical success factors, International Journal of Purchasing and Materials Management, Vol. 30, No. 4, pp. $2-11$.

Trent, R.J. and Monczka, R.M. (1998). "Purchasing and supply Management: trends and changes throughout the 1990s," International Journal of Purchasing and Materials Management, Vol. 34 No. 4, pp. 2-11.

Tushman, M.L. and O’Reilly, C.A. (1996). "Ambidextrous organizations: managing evolutionary and revolutionary change," California Management Review, Vol. 38 No. 4, pp. 8-30. 
van Weele, A.J. (2000). Purchasing and Supply Chain Management, second edition, Thomson: London.

Wasserman, S. and K. Faust (1994). Social Network Analysis: Methods and Applications. New York, NY: Cambridge University Press.

Watts, C.A., Kim, K.Y. and Hahn, C.K. (1992). "Linking purchasing to corporate competitive strategy," International Journal of Purchasing and Materials Management, Vol. 28 No. 4, pp. 2-10.

Weber, R.P. (1990). Basic Content Analysis, second edition, Sage Publications: Newbury Park, California.

Williamson, O.E. (1991). "The logic of economic organization," in The Nature of the Firm: Origins, Evolution and Development, O. E. Williamson and S.G. Winter, ed., New York, NY: Oxford Press.

Wiseman, R. M, Bromiley, P. (1996). "Toward a model of risk in declining organizations: an empirical examination of risk, performance and decline," Organization Science, Vol. 7 No. 5, pp. 524-544. 
Experiencorganization previous (internal) position
Mdtomegent Lru

3ackground Internally Recruited $64 \%$

Figure 1

Supply Initiatives Framework

Supply

$32 \%$

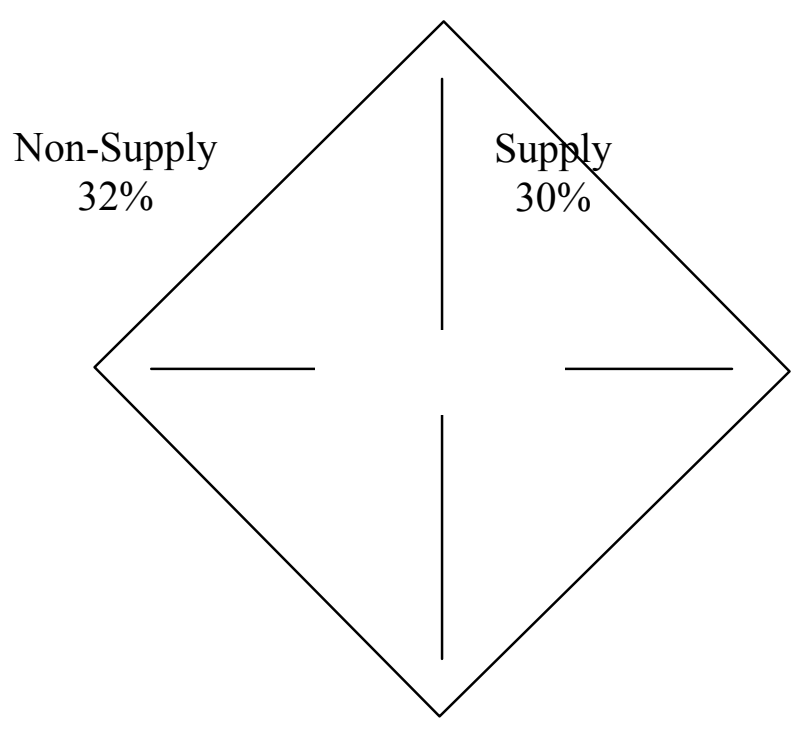

Non-Supply

$6 \%$

Figure 2

CPO Expertise
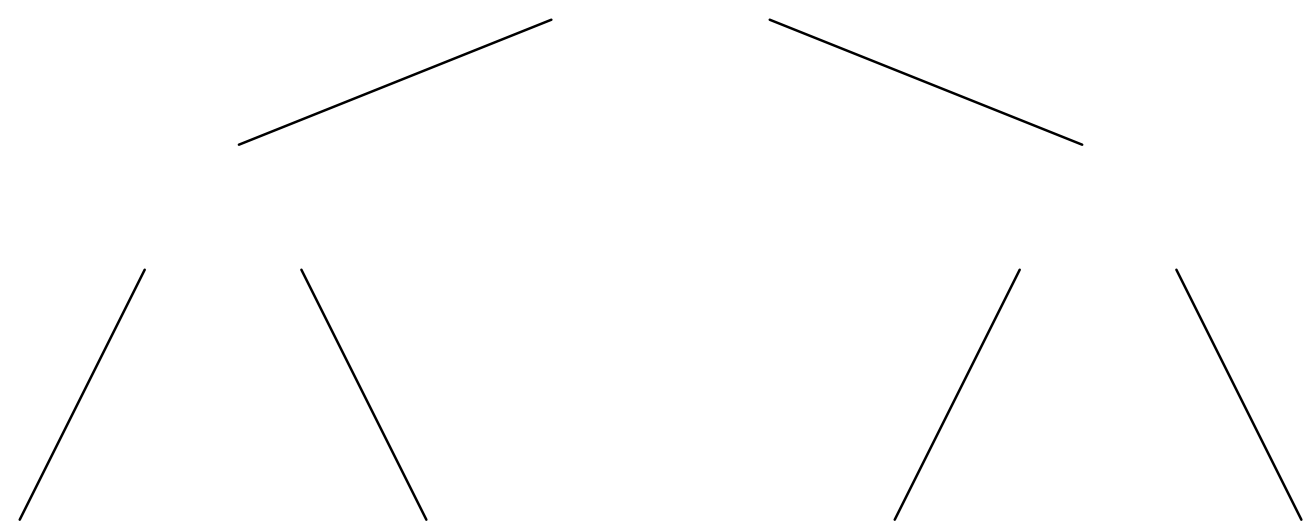
Table 1

Comparison of Categorization Approaches

\begin{tabular}{|c|c|c|c|c|c|}
\hline & \multicolumn{5}{|c|}{ Supply Initiatives Framework } \\
\hline & Supply Strategy & Supply Process & Measurement & Internal Organization & Supply Network \\
\hline $\begin{array}{l}\text { Carter and } \\
\text { Narasimhan (1996) }\end{array}$ & - Outsourcing & $\begin{array}{l}\text { - Transaction cost } \\
\text { management }\end{array}$ & $\begin{array}{l}\text { - Total quality } \\
\text { purchasing } \\
\text { - Time-based purchasing }\end{array}$ & $\begin{array}{l}\text { - Internal organizational } \\
\text { integration }\end{array}$ & $\begin{array}{l}\text { - Supply chain management } \\
\text { - External organizational } \\
\text { integration } \\
\text { - Environmental purchasing }\end{array}$ \\
\hline $\begin{array}{l}\text { Trent and Monczka } \\
\text { (1998) }\end{array}$ & - Supply base management & - Systems development & $\begin{array}{l}\text { - Performance } \\
\text { improvement } \\
\text { requirements } \\
\text { - Performance } \\
\text { measurement }\end{array}$ & $\begin{array}{l}\text { - Supplier and } \\
\text { purchasing/sourcing } \\
\text { importance } \\
\text { - Organization } \\
\text { - Purchasing } \\
\text { responsibilities and } \\
\text { activities } \\
\end{array}$ & \\
\hline Carter et al. (2000) & $\begin{array}{l}\text { - Strategic sourcing } \\
\text { - Supply chain partner } \\
\text { selection and contribution } \\
\text { - Purchasing strategy } \\
\text { development } \\
\text { - Relationship management } \\
\text { - Global supplier } \\
\text { development } \\
\text { - Source development } \\
\text { - Competitive bidding and } \\
\text { negotiation } \\
\text { - Strategic supplier } \\
\text { alliances }\end{array}$ & $\begin{array}{l}\text { - E-Commerce } \\
\text { - Process uncoupling }\end{array}$ & $\begin{array}{l}\text { - Strategic cost } \\
\text { management } \\
\text { - Performance } \\
\text { measurement } \\
\text { - Negotiation strategy }\end{array}$ & $\begin{array}{l}\text { - Tactical purchasing } \\
\text { - Third-party purchasing }\end{array}$ & $\begin{array}{l}\text { - Demand-pull purchasing } \\
\text { - Virtual supply chain } \\
\text { - Complexity management }\end{array}$ \\
\hline
\end{tabular}


Table 2

Characteristics of Respondent Firms

\begin{tabular}{lcc}
\hline \multicolumn{1}{c}{ Annual Sales (in US dollars) } & Frequency & Percentage \\
\hline under $\$ 500$ million & 22 & 8 \\
$\$ 500$ million to $\$ 1$ billion & 19 & 7 \\
$\$ 1$ billion to $\$ 5$ billion & 108 & 38 \\
$\$ 5$ billion to $\$ 10$ billion & 62 & 22 \\
over $\$ 10$ billion & 73 & 25 \\
\hline Total & 284 & 100 \\
\hline
\end{tabular}

Table 3

Taxonomy of E-Business Technologies: Factor Analysis

\begin{tabular}{lccc}
\hline \multicolumn{1}{c}{ E-Business Technology Activity } & Factor 1 & Factor 2 & Factor 3 \\
\hline Electronic / online purchase order system &. $\mathbf{7 6 2}$ & .190 & -.005 \\
Electronic / online supplier catalogue & .721 & .211 & .101 \\
Real-time electronic linkage with suppliers & $\mathbf{. 6 8}$ & .092 & .350 \\
Electronic data interchange (EDI) & $\mathbf{. 6 9 6}$ & .036 & .052 \\
Online bidding / tendering & .296 &. $\mathbf{7 7 4}$ & .063 \\
Online reverse auction / e-auction & .296 &. $\mathbf{7 5 0}$ & .016 \\
Industry-sponsored e-marketplaces (e.g. Covisint) & -.007 &. $\mathbf{7 3 8}$ & .046 \\
Public e-marketplaces (e.g. Global Healthcare Exchange) & .048 &. $\mathbf{7 1 8}$ & .263 \\
Private B2B exchange / Extranet - operated by your company for your & .159 & .064 & $\mathbf{. 7 3 3}$ \\
customer(s) & & .097 & $\mathbf{. 7 2 7}$ \\
Private B2B exchange / Extranet - operated by your company for your suppliers & .282 & .097 \\
Private B2B exchange / Extranet - operated by your customer(s) & -.016 & -.004 & $\mathbf{. 7 1 4}$ \\
Private B2B exchange / Extranet - operated by your supplier(s) & .008 & .198 & $\mathbf{. 6 8 0}$ \\
\hline
\end{tabular}


Table 4

Descriptive Statistics and Correlation Matrix

\begin{tabular}{|c|c|c|c|c|c|c|c|c|c|c|c|c|c|c|c|}
\hline & Variable & Mean & s.d. & 1 & 2 & 3 & 4 & 5 & 6 & 7 & 8 & 9 & 10 & 11 & 12 \\
\hline & Industry Sector & & & & & & & & & & & & & & \\
\hline 1. & Discrete manufacturing ${ }^{a}$ & .262 & .441 & & & & & & & & & & & & \\
\hline 2. & Low capital intensive services ${ }^{a}$ & .169 & .376 & -.269 & & & & & & & & & & & \\
\hline 3. & High capital intensive services ${ }^{a}$ & .191 & .394 & -.290 & -.220 & & & & & & & & & & \\
\hline 4. & $\begin{array}{l}\text { Resource-based firm }^{\text {a }} \\
\text { Firm Characteristics }\end{array}$ & .044 & .205 & -.127 & -.097 & -.104 & & & & & & & & & \\
\hline 5. & $\begin{array}{l}\text { Sales }(2003)^{b} \\
\text { E-Business technology: }\end{array}$ & 3.48 & 1.16 & -.238 & .077 & .171 & -.066 & & & & & & & & \\
\hline 6. & Dyad coordination & 2.95 & .865 & .025 & .074 & .025 & -.158 & .309 & & & & & & & \\
\hline 7. & Private exchange & 1.66 & .673 & .116 & -.076 & -.060 & .068 & .115 & .335 & & & & & & \\
\hline 8. & $\begin{array}{l}\text { Price determination } \\
\text { CPO Level: }\end{array}$ & 1.98 & .829 & -.014 & -.242 & .110 & -.004 & .345 & .362 & .278 & & & & & \\
\hline 9. & Director $^{\mathrm{a}}$ & .251 & .435 & .199 & -.027 & -.058 & -.062 & -.351 & -.129 & .011 & -.156 & & & & \\
\hline 10. & $\begin{array}{l}\text { Vice President }^{\mathrm{a}} \\
\text { Individual Expertise }^{\text {Exide }}\end{array}$ & .634 & .483 & -.063 & .041 & -.034 & .059 & .317 & .217 & .056 & .156 & -.762 & & & \\
\hline 11. & Externally recruited ${ }^{\mathrm{a}, \mathrm{c}}$ & .344 & .476 & .012 & .010 & -.031 & .014 & -.073 & -.096 & .002 & .073 & -.049 & .145 & & \\
\hline 12. & Previous position outside supply ${ }^{\mathrm{a}, \mathrm{d}}$ & .350 & .478 & -.099 & -.026 & .255 & -.045 & .161 & -.036 & -.172 & .048 & -.082 & .010 & -.314 & \\
\hline 13. & Years in supply ${ }^{\mathrm{e}}$ & 2.15 & 1.10 & .048 & .055 & -.171 & -.068 & -.186 & .036 & .036 & .057 & .091 & -.066 & .335 & -.593 \\
\hline
\end{tabular}

\section{Notes}

$\overline{\mathrm{N}=183} ;|\rho| \geq .199$ are statistically significant at $p<.01$; and $|\rho| \geq .156, p<.05$.

${ }^{\text {a }}$ Dichotomous variable, coded as 1 if true, 0 otherwise. Spearman Correlations are reported for these variables.

${ }^{\mathrm{b}}$ Sales were reported on a five-point scale

${ }^{\mathrm{c}}$ Externally recruited: 1 = Manager recruited from outside the firm

${ }^{\mathrm{d}}$ Previous position outside supply: 1 = Manager most recently worked outside the Supply/Purchasing function

e Logarithmic transformation 
Table 5

Results of Logistic Regression Analysis for Supply Initiatives

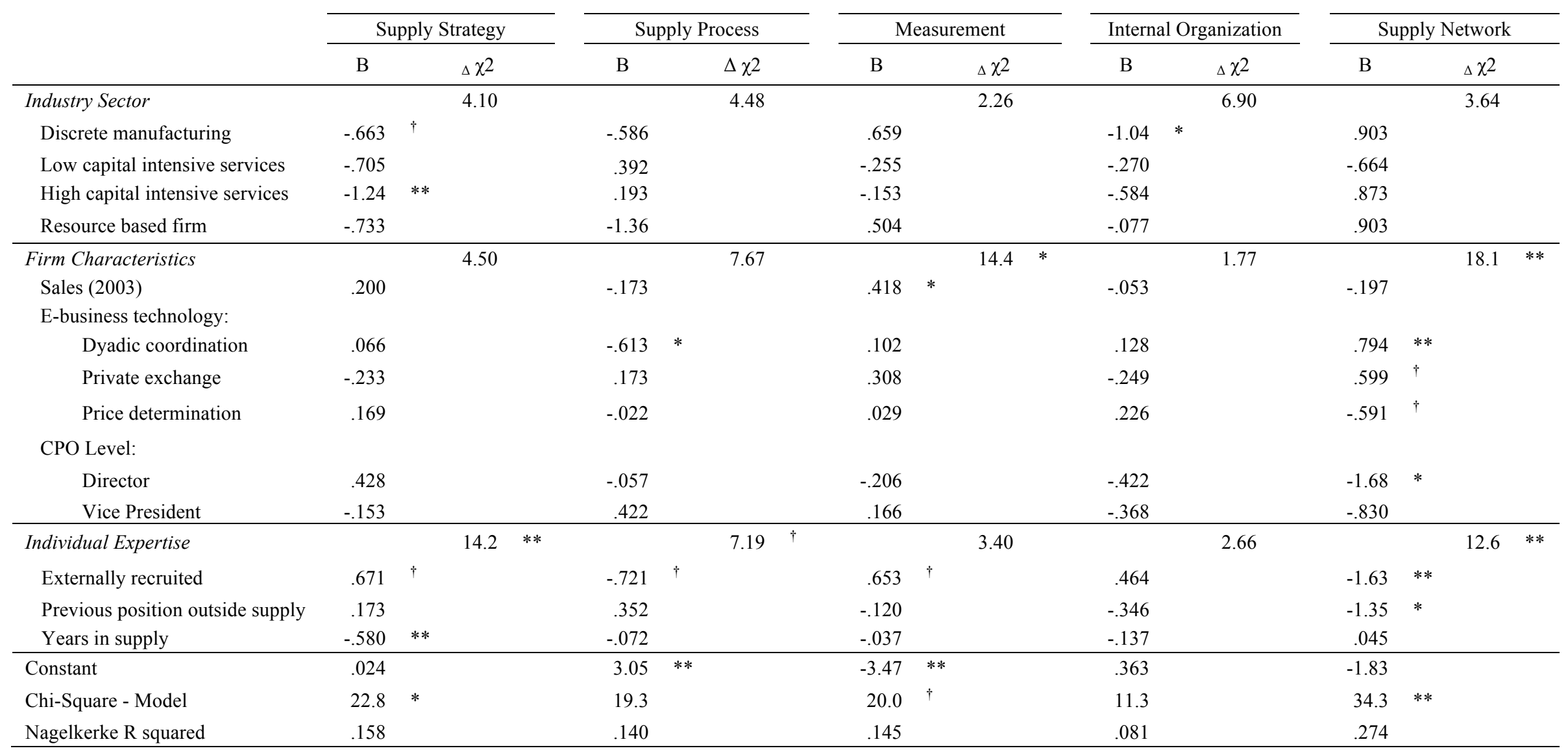

$$
\begin{array}{ll} 
& \mathrm{N}=183 \\
\dagger & \mathrm{p} \leq 0.10 \\
* & \mathrm{p} \leq 0.05 \\
* * & \mathrm{p} \leq 0.01
\end{array}
$$

